\title{
The Impact of Macroeconomic Factors on the Revenues of the Sovereign Wealth Funds
}

\author{
Isabella Damdinova Elyakova ${ }^{1}$, Elena Leonidovna Chizhevskaya ${ }^{2} \&$ Margarita Semenovna Smialowskaya $^{3}$ \\ ${ }^{1}$ Doctor of Economics, professor, North-Eastern Federal University, Yakutsk, Russian Federation \\ ${ }^{2}$ Associate Professor, Centre of business education of the Institute of management and business, Tyumen State \\ Oil and Gas University, Tyumen, Russian Federation \\ ${ }^{3}$ Doctor of Economics, professor, the department of economics and management, the faculty of economics, \\ management and law, Russian state university of tourism and service, Moscow, Russian Federation
}

Correspondence: Isabella Damdinova Elyakova, North-Eastern Federal University, 677000 Yakutsk, Russian Federation. E-mail: elyak@list.ru

Received: December 30, 2014

Accepted: December 30, 2014

Online Published: March 25, 2015

doi:10.5539/mas.v9n5p105

URL: http://dx.doi.org/10.5539/mas.v9n5p105

\begin{abstract}
Development and improvement of the sovereign wealth funds of the unfavourable geopolitical situation, when world oil prices since mid-summer continue to decline, has become more urgent. The current economic and political situations shall have the volume of the funds financial resources estimated by analysing the impact of major macroeconomic indicators such as growth and decline in oil exports, changes in oil prices and the dollar exchange rate on the formation of the sovereign wealth funds of national welfare of states in the future to predict changing of these factors on changes in the volume of funds. The article analyses the key macroeconomic factors affecting the formation and use of proceeds of sovereign funds by many countries, not only aimed at preserving capital and achieving long-term profitability, but also for sustainable economic growth in their countries and regions. The studies revealed that revenues in sovereign funds have a significant impact following factors: the price of oil and the dollar exchange rate of the national currency. Supply and demand of oil in the world market have little effect, but in times of crisis of 2008-2009, their effect significantly increases.
\end{abstract}

Keywords: information systems, applied science, sovereign fund, National Welfare Fund, investment, exports, oil amount, oil price, dollar exchange rate, macroeconomic factors

\section{Introduction}

Achieving the welfare of the people is the supreme goal of society from the ancient times to the present. Aristotle, who identified the principal criteria of differentiation as the amount of ruling people in the state and the goal performed by the state, considered the state to be right if it achieves the common good (Ibraev, 2013). The Russian Federation is a social state which policy is aimed at creating conditions for a dignified life and free development rights (the Constitution of Russia, 1993). Therefore, the task of the state of the President and the Government of the Russian Federation is to ensure the welfare of their people.

When considering the conditions of welfare funds occurrence, there shall be noted the overall favourable trend of post-war development of the developed countries economies in 1960-80's of the XX century, such as high rates of economic growth, active industrialization and modernization of the economy, due to the phenomenon of catch-up, joining the developed countries in the era of scientific and technological revolution, the rising cost of hydrocarbon raw materials.

During this period, the sovereign wealth funds were created in the United States, Canada, Singapore, the United Arab Emirates, Chile, Oman, and Brunei. The funds accumulated foreign currency from oil sales, which influx to the economies threatened to cause "overheating", so it was better to withdraw from their country budgets and generate investment funds for the binding of excess liquidity.

The sharp rise in oil prices since the beginning of the 2000s until mid-2008 ensured the growth of foreign exchange reserves to record high levels (average annual rate amounted to about $20 \%$ ).

At the same time, many large international investors placed large amounts of capital goods in the commodities 
market (or derivatives of securities which underlying asset is raw materials) in order to diversify their investments. The balance of developing countries payments, against this background, showed growth of the current account, while in developed countries, there was an inverse dynamics. This situation in the global economy caused the third and the most significant wave of formation of sovereign funds in their entire history. Therefore, if at the end of the 1990s at least 20 sovereign funds were functioning in the world, by the end of 2012, their number more than tripled (Ibraev, 2013).

It is important to note that wealth funds are established not only within the country but also across the region. For example, in the Republic of Sakha (Yakutia), since 1993, the Trust fund for future generations, which funds are directed to the construction of social facilities: general education, vocational and higher education institutions, sports facilities, funds for the development of material and technical base of health care institutions of the Republic (Petrikova, 2012). The sources for replenishment are gratuitous donation of "ALROSA" OJSC of return based on a socio-economic development of the Republic of Sakha (Yakutia) between the Government of the Republic of Sakha (Yakutia) and "ALROSA" (OJSC). In 2013, the shares by "ALROSA" (OJSC) were placed, 7\% stake is the share of the Government of the Republic of Sakha (Yakutia) was bought for 18 billion RUR (Official site of the Government of Republic of Sakha (Yakutia) [Electronic resource]). The proceeds from the sale of funds for roubles were sent to the company "RIK+" OOO (Official site of the Government of Republic of Sakha (Yakutia) [Electronic resource]). After paying the tax income, the money will start to work for the republic. Basic proceeds from the sale of shares will be used for the demolition of dilapidated housing, gasification, utilities, construction Cancer Centre, social projects, including 6.4 billion - to demolition, 2.2 bln — cancer centre, $2.6 \mathrm{bln}$ — social establishments, $4 \mathrm{bln}$ — gasification, housing - $2.6 \mathrm{bln}, 550 \mathrm{mln}$ construction of courts (Official site of the Government of Republic of Sakha (Yakutia) [Electronic resource]). "The main thing is improving people's lives», - said the president of the Republic of Sakha (Yakutia), Egor Borisov.

Thus, the objective conditions for the world economy, including alternating periods of growth and periods of crisis, the realization of economic and financial interdependence of states within the framework of globalization and the growing awareness of the need mainly substitution of exhaustible resources, financial investments pushed to the emergence of sovereign wealth funds of the Institute.

\section{Literature Review}

The idea of using currency as a measure of well-being emerged, apparently, simultaneously with the appearance of money, but as a theoretical concept, it took first shape within the framework of mercantilism in the XV century. Representatives of mercantilism saw the money as the main wealth of the state. A prominent Russian economist, I.T.Pososhkov (1652-1726), in "The Book of Poverty and Wealth..." proposed to achieve the wealth of the state (treasury) by restricting luxury goods import, stopping industrial raw materials export, and exporting only finished products (Pososhkov, 1951).

The background of the sovereign funds at the state level go back only to the end of XVIII - early XIX centuries. For the first time, the theoretical justification for the establishing funds of this type in order to reach the safety of the nation's resources and future savings can be found in the papers by Adam Smith (1723 - 1790). In his paper on the nature and causes of the wealth, the famous economist reflected his ideas in detail about the need to create a national fund. In this paper, he also proposed options for managing the fund accumulation. Forming of this type of fund, according to Smith, is due to removal of part of the profit from the income of large enterprises (A. Smith).

The principles of scientific approach in the papers by famous thinkers of that time are based primarily on the nature of constituent state funds that seek to protect the nation from affecting social wealth changes occurring over time. Thus, these ideas are reflected in such contemporary issues as the reduction or negative changes in oil and gas revenues in the budget (and other natural resources), inflationary pressures on the economy, the imbalance of pension savings, the state budget deficit, and others (Ibraev, 2013, p. 94).

For a more clear definition of the conditions for the appearance of modern sovereign funds, it is necessary to look at the history of their creation, counting six decades. Despite the relatively short period of existence of funds, researchers distinguish several stages in the formation of state sovereign wealth funds. Thus, R. H. Ibraev identifies the three stages in the funds formation: the first stage - 1953-1960; the second stage - 1961-1999; the third stage - 2000-present (Ibraev, 2013, p. 98).

The first National Welfare Fund was established in February 1953 in London, Kuwait Investment Board, financed by the profits from the sale of Kuwaiti oil (Ibraev, 2013, p. 96). 
Due to the accumulation of capital, a system of governmental management was established that allowed Kuwait in 1961 to declare its independence from Great Britain (Ibraev, 2013, p. 98).

In 1958, the income tax on the exports of phosphates, the only mine minerals on Hilbert Islands, the Reserve Fund for income equalization in Kiribati was established (Ibraev, 2013, p. 98).

The Norway's experience to create a stabilization fund can be useful for Russia (Danilina, 2004). In Russia, the history of creation and development of sovereign funds has a special character. Primarily, their creation is associated with the idea of institutionalized state budget surplus, which is formed in the form of account balances of the budget in the Russian Central Bank (Kudrin, 2006).

Thus, the sovereign wealth fund is a special state fund set up by revenues from exports of natural resources or due to foreign exchange reserves of the country.

\section{Materials and Methods}

When considering the conditions of welfare funds occurrence, there shall be noted the overall favourable trend of post-war development of the developed countries economies in 1960-80's of the XX century, such as high rates of economic growth, active industrialization and modernization of the economy, due to the phenomenon of catch-up, joining the developed countries in the era of scientific and technological revolution, the rising cost of hydrocarbon raw materials.

During this period, the sovereign wealth funds were created in the United States, Canada, Singapore, the United Arab Emirates, Chile, Oman, and Brunei. The funds accumulated foreign currency from oil sales, which influx to the economies threatened to cause "overheating", so it was better to withdraw from their country budgets and generate investment funds for the binding of excess liquidity.

The sharp rise in oil prices since the beginning of the 2000s until mid-2008 ensured the growth of foreign exchange reserves to record high levels (average annual rate amounted to about $20 \%$ ).

Before assessing the impact of macroeconomic indicators on the strategy of sovereign funds, it is necessary to consider the volume of assets of the largest sovereign wealth funds of states and choose sovereign wealth funds, the most suitable for the analysis. As of September 1, 2013, according to the Institute of sovereign wealth funds, about 70 sovereign wealth funds were created in the world, among the total number, the Institute allocated 10 largest funds in terms of assets, the total value of assets is $4630.7 \mathrm{bln}$. USD, or $79 \%$ of the value of the sovereign wealth funds' assets in the world (Institute of sovereign wealth funds, 2014). Table 1 shows the amount of the largest sovereign wealth funds' assets.

Table 1. The volume of assets of the largest sovereign wealth funds, USD bln (as of Sep 01, 2013)

\begin{tabular}{clcc}
\hline S/ & \multicolumn{1}{c}{ Name } & State & $\begin{array}{c}\text { The volume of assets, } \\
\text { USD bln }\end{array}$ \\
\hline N & Government Pension Fund - Global & Norway & 737.2 \\
2 & Foreign assets of the Monetary Authority of Saudi & Saudi Arabia & 675.9 \\
& Arabia & & \\
3 & Abu Dhabi Investment Authority & UAE & 627.0 \\
4 & China Investment Corporation & China & 575.2 \\
5 & SAFE Investment Company & China & 567.9 \\
6 & Kuwait Investment Authority & Kuwait & 386.0 \\
7 & Hong Kong Monetary Authority investment authority & Hong Kong & 326.7 \\
8. & Government of Singapore Investment Corporation & Singapore & 386.0 \\
9 & National Welfare Fund & Russian Federation & 175.5 \\
10 & Temasek Holding & Singapore & 173.3 \\
& TOTAL & & 4630.7 \\
& TOTAL & & 5470.0 \\
\hline
\end{tabular}

* Institute of Sovereign Wealth Funds, 2014.

As can be seen from the table, more than $54 \%$ of its assets are concentrated in five sovereign wealth funds of Norway, Saudi Arabia, the United Arab Emirates, and China, which indicates considerable potential macroeconomic impact of investment decisions of fund managers (Institute of sovereign wealth funds, 2014). As mentioned above, the majority of the sovereign wealth funds managed by public authorities through the 
establishment of regulatory rates of return for different types of investments, limit the scope of investments in specific types of asset management costs, etc.

It shall also be noted that the rapid growth of sovereign wealth funds has occurred in the period from 2000 to 2012, when stock prices for hydrocarbons have risen to record levels, i.e. a significant inflow of funds more than 2.5 billion USD entered into the commodity funds. Source of funding for non-resource funds usually have foreign exchange reserves surplus.

Given that basic raw material commodities, which export brings superproficits to countries' public budgets, is oil, it is necessary to consider the dynamics of prices and volumes of its global production and consumption since 1970 to determine the effect of oil prices on the increase in the total assets of the sovereign funds of Norway and Russia. Change in oil prices between 1970 and 2012 is presented below at the Figure 1.

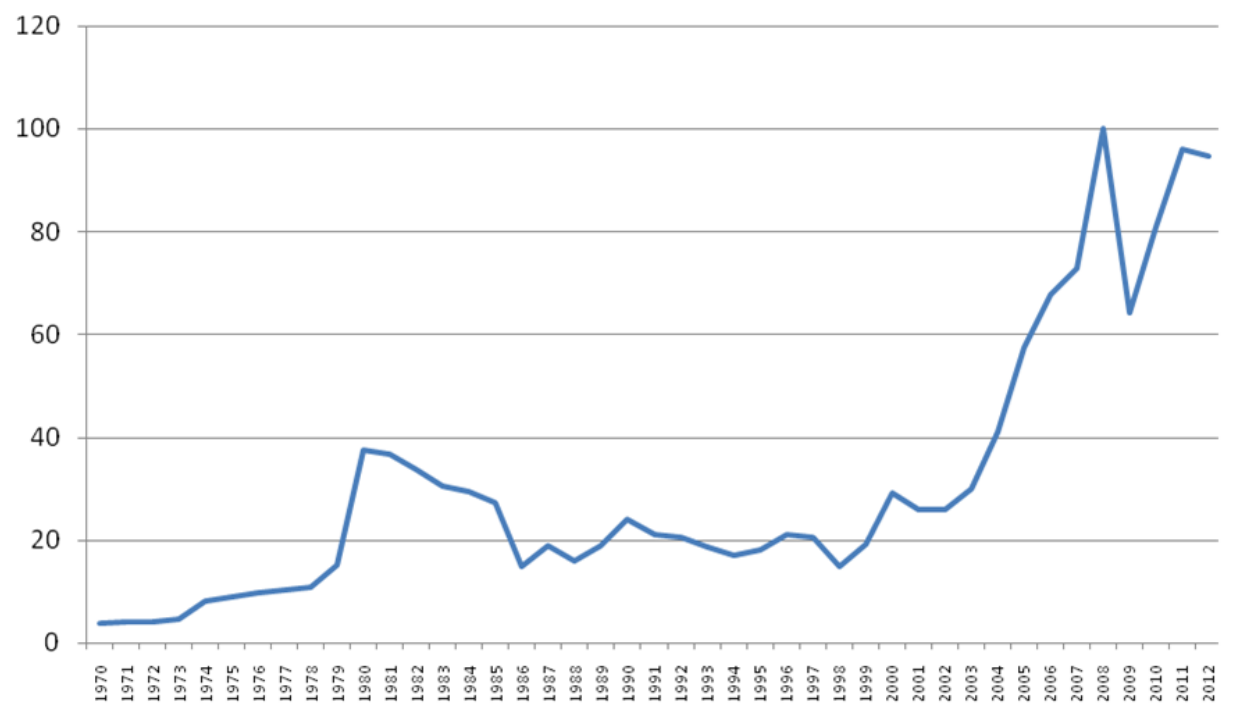

Figure 1. The dynamics of oil prices for the 1970-2012 in USD/bbl

As it can be seen from the chart, the price of oil has increased by 25 times: from 4 USD/Bbl to 95 USD/Bbl. In order to determine the degree of supply and demand fundamentals influence on the oil price, it is necessary to compare the volumes of oil production and consumption for a long period the same as for the period of the world oil prices changes. The dynamics of oil production and consumption in the period from 1970 to 2012 is shown in Table 2.

Next, we consider the dynamics of the dollar exchange rate compared to rouble and Norwegian krone, starting the replenishment periods of sovereign funds. The Norwegian Fund received the first instalment in 1996, while the Russian - in 2004 (Rzhevskaya, 2011). Figure 2 shows the fluctuation of the dollar exchange rate to the rouble exchange rate from 2003 to 2013. 


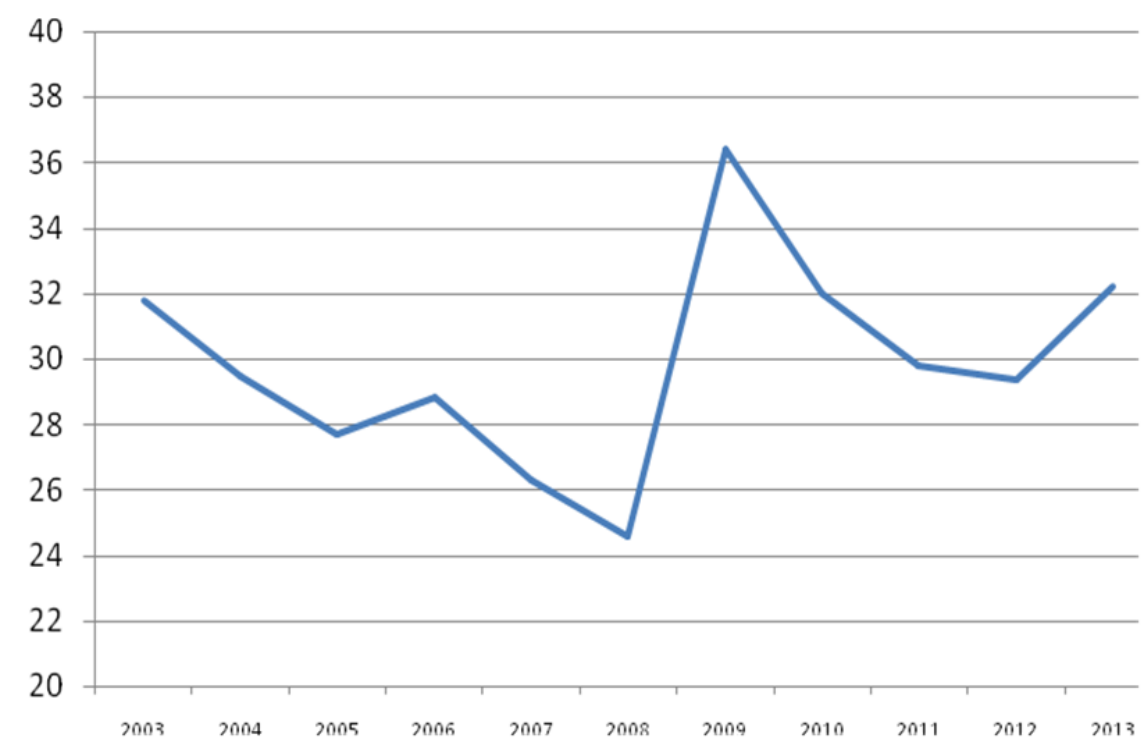

Figure 2. The dynamics of dollar exchange rate compared to rouble for 2003-2013, in RUR/USD

Dollar exchange rate in the period under review varied at the level of 30-32 roubles per 1 dollar. Sharp fluctuations in the dollar exchange rate compared to rouble were caused by the global financial crisis of 2008-2009. In this period, the maximum dollar exchange rate was 36 roubles, the lowest in $2008-25$ roubles (Sukharev, O., 2009).

Changing the dollar exchange rate in relation to the Norwegian krone for the period 1995-2012 is shown in Figure 3.

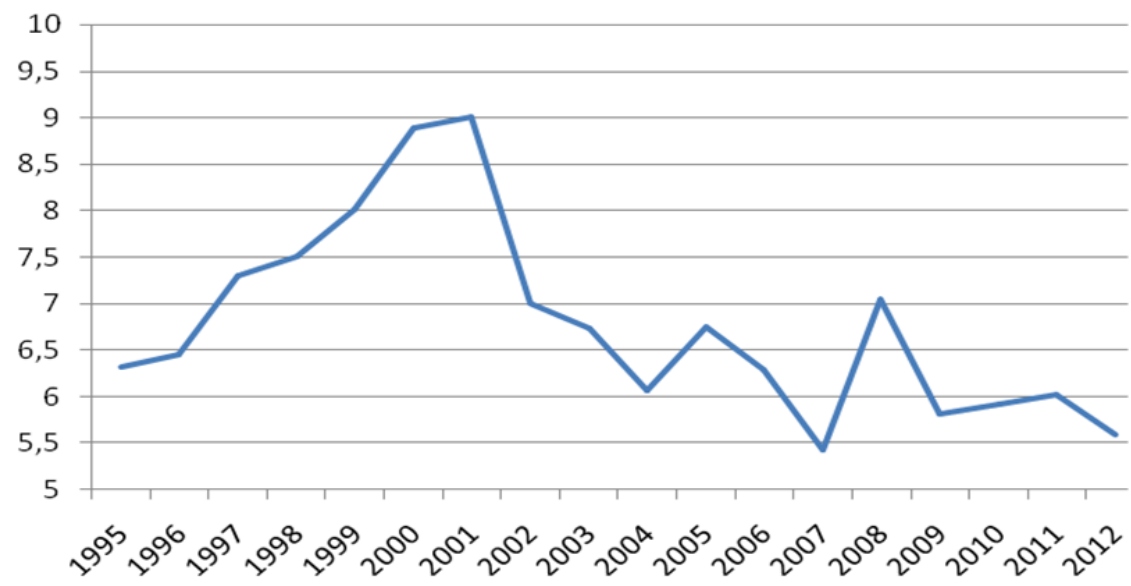

Figure 3. The dynamics of the US dollar exchange rate compared to the Norwegian krone for 1995-2013 (NOK/USD)

The dynamics of the dollar exchange rate despite the upward trend from 1995 to 2001, when the dollar exchange rate rose to $9 \mathrm{NOK}$ tends to decrease with respect to the Norwegian krone. During the crisis, there was a decline rate by 1.6 krone after a peak at 7 Norwegian krones/USD, and by the end of 2012, one dollar equalled to 5.5 Norwegian krones.

Thus, the comparison of the dollar against the national currency of Norway and Russia showed that the decline in oil prices in 2009 affected the depreciation of the currency, that is, the value of the US dollar rose against the rouble and Norwegian krone. 
In addition, the graphical analysis showed that the price of oil on the world market is susceptible to changes: from 2000 to 2008 , the price rose from $30 \mathrm{USD} / \mathrm{Bbl}$ to $100 \mathrm{USD} / \mathrm{Bbl}$., or $342 \%$ and then fell sharply to 65 $\mathrm{USD} / \mathrm{Bbl}$, and increased again to $95 \mathrm{USD} / \mathrm{Bbl}$.

At that, graphics of changes in world oil production and consumption, despite the sharp fluctuations in the period from 1975 to 1982, are characterized by steady planned growth in 2012 compared to 2000, production and consumption increased from about 3.6 billion $t$ to 4100 million $t$, or $13-15 \%$, i.e. the price of oil, in addition to global supply and demand, is significantly influenced by other factors.

In this study, the price of oil is seen as a major factor in increasing revenues of the sovereign funds. The additional factor is the dollar exchange rate of the national currency.

\section{Discussion and Results}

The carried assessment of the impact of key macroeconomic factors on the revenue of the sovereign funds for the period of 1996-2012. demonstrated that due to increased revenue from oil exports, there was an increase of assets of sovereign funds: incomes to the fund of Norway increased by 7 times, the Russian Stabilization Fund by 5 times. Table 2 shows the results of assessing the impact of key macroeconomic factors on the revenue formation of the sovereign funds for the period 1996-2012.

Table 2. Assessing the impact of key macroeconomic factors on the revenue of the sovereign funds for the period of 1996-2012. (as of Jan 01, 2013)

\begin{tabular}{|c|c|c|c|c|c|c|c|}
\hline \multirow[t]{3}{*}{$\mathbf{S} / \mathbf{N}$} & \multirow{3}{*}{ Factors } & \multicolumn{3}{|c|}{ Norway } & \multicolumn{3}{|c|}{ Russian Federation } \\
\hline & & $\begin{array}{c}\text { First } \\
\text { instalment } \\
\text { year }\end{array}$ & $\begin{array}{l}\text { Fiscal } \\
\text { year }\end{array}$ & \multirow[t]{2}{*}{$\begin{array}{c}\text { Rel. } \\
\text { change, \% }\end{array}$} & $\begin{array}{c}\text { First } \\
\text { instalment } \\
\text { year }\end{array}$ & $\begin{array}{c}\text { Fiscal } \\
\text { year }\end{array}$ & \multirow[t]{2}{*}{$\begin{array}{c}\text { Rel. } \\
\text { change, \% }\end{array}$} \\
\hline & & 1996. & 2012 & & 2004 & 2012 & \\
\hline 1 & \multicolumn{7}{|l|}{ Macroeconomic factors } \\
\hline 1.1. & $\begin{array}{l}\text { Revenues from oil exports, } \\
\text { bln.cr/bln. RUR }\end{array}$ & 135 & 309 & $227 \%$ & 1770 & 5760 & $325 \%$ \\
\hline 1.2 . & Oil price, USD/Bbl & 21 & 95 & $452 \%$ & 41 & 95 & $232 \%$ \\
\hline 1.3 . & Oil exports, $\mathrm{mln} t$ & 137 & 68 & 50 & 260 & 240 & $92 \%$ \\
\hline \multirow[t]{2}{*}{1.4.} & $\begin{array}{l}\text { Dollar exchange rate, } \\
\text { nat.cur.it./USD }\end{array}$ & 6.3 & 5.6 & $115 \%$ & 30 & 32 & $107 \%$ \\
\hline & $\begin{array}{l}\text { Assets volume, bln. USD, } \\
\text { total: }\end{array}$ & 7 & 681 & $\begin{array}{l}\text { by } 97 \\
\text { times }\end{array}$ & 16 & 89 & $\begin{array}{l}\text { by } 5 \\
\text { times }\end{array}$ \\
\hline 2 & \multicolumn{7}{|c|}{ Influence of factors on the amount of assets } \\
\hline & $\begin{array}{l}\text { Revenue from sovereign } \\
\text { wealth funds, USD bln }\end{array}$ & 7 & 49 & $709 \%$ & 16 & 89 & $556 \%$ \\
\hline 2.1 . & $\begin{array}{l}\text { due to changes in oil export } \\
\text { revenues }\end{array}$ & - & +172 & & - & +3990 & \\
\hline 2.2 . & due to changes in the oil price & - & +74 & & - & +54 & \\
\hline 2.3 . & $\begin{array}{l}\text { due to changes in oil export } \\
\text { volume }\end{array}$ & - & -69 & & - & -20 & \\
\hline 2.5 . & $\begin{array}{l}\text { due to changes in the dollar } \\
\text { exchange rate }\end{array}$ & - & $-0,7$ & & - & +2 & \\
\hline
\end{tabular}

* Review of materials based on the results of reports by the Statistics Bureau of Norway, the Central Bank of the Russian Federation, the Federal State Statistics Service, the companies of BP, the Ministry of Finance, and the Investment Management of the Norwegian bank.

Also, note that although the source of revenue in sovereign wealth funds is formed by the export of oil and gas, the paper investigates the impact of oil exports changes only.

Assessing the impact of key macroeconomic factors on the revenue formation of the sovereign funds for the period 1996-2012, it is clear, first, that Norway state budget revenues from oil exports during 16 years grew from 135 billion krones in 1996 to 307 billion krones in 2012, or 227\%, in Russia, the growth of this indicator during 8 years comprised $305 \%$. The increase in oil and gas revenues was due to the huge impact of changes in oil 
prices: in 1996 the price increased by 4.5 times, in 2004 - by 2.3 times; while natural oil exports declined: in Norway - from 137 million t. in 1996 to 68 million $t$ in 2012, or 50\%, while in Russia - from 260 million t in 1996 to 240 million $t$ in 2012, or by $8 \%$. Due to increased revenue from oil exports, there was an increase of assets of sovereign funds: incomes to the fund of Norway increased by 7 times, the Russian Stabilization Fund by 5 times.

The influence of key macroeconomic indicators for the use of Sovereign Wealth Funds in the dynamics of the change periods of these parameters on the example of Norway and Russia since the year contributions to the sovereign fund and ending with 2012 reporting year. Table 3 shows the evaluation of the impact of key macroeconomic indicators for the sovereign wealth funds use for the period 1996-2012.

Table 3. Assessing the impact of key macroeconomic factors on using the assets of the sovereign funds for the period of 1996-2012. (as of Jan 01, 2013)

\begin{tabular}{|c|c|c|c|c|c|c|}
\hline \multirow[b]{2}{*}{ Index } & \multicolumn{3}{|c|}{ Norway } & \multicolumn{3}{|c|}{ Russian Federation } \\
\hline & $\begin{array}{c}\text { First } \\
\text { instalme } \\
\text { nt year } \\
1996\end{array}$ & $\begin{array}{c}\text { Fiscal } \\
\text { year } \\
2012\end{array}$ & $\begin{array}{c}\text { Rel. } \\
\text { chang } \\
\text { e, \% }\end{array}$ & $\begin{array}{c}\text { First } \\
\text { instalment } \\
\text { year } \\
2004\end{array}$ & $\begin{array}{c}\text { Fiscal } \\
\text { year } \\
2012\end{array}$ & $\begin{array}{c}\text { Rel. } \\
\text { chang } \\
\text { e, \% }\end{array}$ \\
\hline GDP bln.cr/bln. RUR & 1033 & 2909 & 282 & 17027 & 61811 & 363 \\
\hline incl. due to the oil and gas extraction & 148 & 681 & 460 & 1412 & 5862 & 415 \\
\hline Public debt, bln.cr/bln.RUR & 285 & 617 & 216 & 3630 & 1632 & 42 \\
\hline Public debt, $\%$ of GNP & $28 \%$ & $21 \%$ & $-7 \%$ & $21 \%$ & $3 \%$ & $-18 \%$ \\
\hline Total residential area, sq.m/pers. & $\mathrm{n} / \mathrm{a}$ & 58.5 & - & 20.1 & 23.4 & $117 \%$ \\
\hline $\begin{array}{l}\text { Average monthly salary, nat. cur.it./ } \\
\text { person, }\end{array}$ & $\mathrm{n} / \mathrm{a}$ & 40800 & - & 8555 & 23369 & 273 \\
\hline Assets volume, bln USD & 7 & 681 & $\begin{array}{l}\text { by } 97 \\
\text { times }\end{array}$ & 16 & 89 & $\begin{array}{l}\text { by } 5 \\
\text { times }\end{array}$ \\
\hline Investment structure, $100 \%$, incl.: & - & 100 & - & - & 100 & - \\
\hline - financial assets of shares, $\%$ & - & 60 & - & - & - & - \\
\hline - financial assets of bonds, currency, $\%$ & - & 39 & - & - & 100 & - \\
\hline - real assets, $\%$ & - & $1 \%$ & - & - & - & - \\
\hline
\end{tabular}

Having analysed the data presented, it can be concluded that the priorities of the direction of Sovereign Wealth Funds are largely determined by the achieved macroeconomic indicators of the state. Thus, a high level of average monthly salary in the amount of NOK 40800 per person, sufficient supply of housing area in the amount of $58.5 \mathrm{sqm} /$ per person, acceptable level of public debt at $21 \%$ of the fund's investments determine the direction of the external financial markets and asset markets in developing countries. At the same time, poor indicator values in Russia define conservative strategy for the retention and preservation of Sovereign Wealth Funds in liquid assets. The level of public debt in 2012 amounted to 3\% of GDP due to a reduction at the expense of its sovereign fund.

\section{Conclusion}

Effective use of Sovereign Wealth Funds requires coordination from the state. This is due not only to the state origin of the funds, but also the strategic goal of a sovereign fund to ensure the preservation and enhancement of the national wealth.

If the mining volume data and oil consumption are compared over the period from 1970 to 2012 , it can be seen that the excess of demand over supply of oil was noted in 1985, 1987, 1999, 2002, 2007-2012, or 12 periods of 43 considered; total unsecured demand of 356 million $t$, or less than $10 \%$ of the annual production or consumption. Thus, we can conclude that the growth rates, hence the increase in oil revenues, are slightly influenced by the factors of increased demand and supply of oil, but in times of crisis of 2008-2009 their influence grew significantly.

Assessing the impact of key macroeconomic factors on the revenue formation of the sovereign funds for the 
period 1996-2012, it is clear, that Norway state budget revenues from oil exports during 16 years grew from 135 billion krones in 1996 to 307 billion krones in 2012, or $227 \%$, in Russia, the growth of this indicator during 8 years comprised $305 \%$.

The increase in oil and gas revenues was due to the huge impact of changes in oil prices: in 1996 the price increased by 4.5 times, in 2004 - by 2.3 times; while natural oil exports declined: in Norway - from 137 million t. in 1996 to 68 million $t$ in 2012, or 50\%, while in Russia - from 260 million $t$ in 1996 to 240 million t in 2012, or by $8 \%$. Due to increased revenue from oil exports, there was an increase of assets of sovereign funds: incomes to the fund of Norway increased by 7 times, the Russian Stabilization Fund - by 5 times.

The result of analysing the impact of macroeconomic factors on the revenue of the sovereign wealth funds, such as the analysis of oil exports dynamics, changes in crude oil prices and the dollar exchange rate in relation to the Norwegian krone and Russian rouble, it can be concluded that the factors of oil price changes and the dollar against the national currency have a significant influence on the formation of raw superproficits of government budgets and thus the formation of sovereign wealth funds, even with a gradual decrease of the actual oil exports volume.

\section{References}

Danilina, M. V. (2004). Functioning of the state oil stabilization fund (the experience of Norway). Problems of Forecasting, 4, 59-69.

Danilina, M. V. (2004). On the formation and management of the Stabilization Fund of the Federal budget of the Russian Federation. Proceedings of Institute of Economic Forecasting of RAS. - T. 2, 93-111.

Investment management (2001). Blank I. A. M.: Elga, Nika-Tsentr.

Khimicheva, N. I., \& Pokachalova, E. V. (2005). Financial Law: training complex (pp. 464). M.: Norma.

Kudrin, A. L. (2006). Stabilization Fund: foreign and Russian experience. Economics Questions, 2, 28-45.

Ministry of finance of Norway. Introduction to the GPFN and GBF. [Digital resource]. Retrieved from http: www.regjeringen.no/pages/37984862/GPFN_and_GBF_April2013.pdf

Official site of the Government of the Republic of Sakha (Yakutia). Funds from the sale of the shares of ALROSA will help solving the problems of Yakutia. [Digital resource]. Retrieved from http: sakha.gov.ru

Official site of the Ministry of Finance of the Russian Federation. [Digital resource]. Retrieved from http:.info.minfin.ru/pf.php

Official site of the Ministry of Finance of the Russian Federation. On the Stabilization Fund of the Russian Federation. [Digital resource]. Retrieved from http: www.minfin.ru/ru/stabfund/about/

Official site of the Ministry of Finance of the Russian Federation. [Digital resource]. Retrieved from http: www1.minfin.ru/ru/

Official site of the Treasury of the Russian Federation. Data on actual enrolment, cancellation and balances. [Digital resource]. Retrieved from http: roskazna.ru/stabilizatsionnyy-fond-rossiyskoy-federatsii/

Official site of the Treasury of the Russian Federation. Information about the funds movement of the Stabilization Fund of the Russian Federation. [Digital resource]. Retrieved from http:.roskazna.ru/stabilizatsionnyy-fond-rossiyskoy-federatsii/

Official site of the Treasury of the Russian Federation. Information about the funds movement of the Stabilization Fund of the Russian Federation. [Digital resource]. Retrieved from http:.roskazna.ru/stabilizatsionnyy-fond-rossiyskoy-federatsii/

Official site of the Treasury of the Russian Federation. Information about the funds movement over the accounts of the Federal Treasury to record funds of oil and gas revenues of the Federal budget, the Reserve Fund, and the National Welfare Fund. [Digital resource]. Retrieved from http:.roskazna.ru/svedeniya-o-dvizhenii-sredstv-po-schetam

Organisation for Economic Co-operation and Development. [Digital resource]. Retrieved from http: www.oecd-ilibrary.org/economics/country-statistical-profile-russian-federation_20752288-table-rus

Petrikova, E. M. (2012). Sovereign wealth funds of the country as a tool for stabilization the financial market. Finances and Credit, 10, 39-49.

Pososhkov, I. T. (1951). Book on poverty and wealth. - M., Publishing House of the Academy of Sciences of the USSR. 
Report No. 27 to the Storing (2012-2013). The Management of the Government Pension Fund in 2012. Retrieved from http: www.regjeringen.no/pages/7772/chapter1_2.pdf

Report No. 27 to the Storing (2012-2013). The Management of the Government Pension Fund in 2012.

Rzhevskaya T. (2011). Stabilization funds of foreign countries. Bulletin of the Institute of Economics of RAS, 2 , 172-179.

Shulyak, P. N., \& Belotelova, N. I. (2000). Finance: Textbook. M.: Urait.

State Statistics of Norway. Retrieved from http:.www.ssb.no/en/

Sukharev, A. N. (2009). Reserve Fund and National Welfare Fund: financial structure and results of functioning. Finances and Credit, 40, 50-59.

SWF Institute. Retrieved from http: www.swfinstitute.org/swfs/oman-state-general-reserve-fund

SWF Institute. Retrieved from http: www.swfinstitute.org/statistics-research/linaburg-maduell-transparency-index/

SWF Institute. Retrieved from http:.www.swfinstitute.org/fund-rankings/

SWF Institute. Retrieved from http:.www.swfinstitute.org/fund/saudi.php

The Constitution of the Russian Federation (Chapter 1, Article 7) - M., 1993

The Russian newspaper. Retrieved from http:.www.rg.ru/2012/01/11/proficit-anons.html

The Sovereign Wealth Fund Initiative. (2012). Profile: Government Pension Fund Global. Retrieved from http:fletcher.tufts.edu/SWFI/ /media/Fletcher/Microsites/swfi/pdfs/2012/profiles/Norway\%20Fund\%20Pro file.pdf

VolIbraev, R. H. (2013). The role of sovereign funds in today's global capital market. Russian External Economic Bulletin, 9, 94-98.

\section{Copyrights}

Copyright for this article is retained by the author(s), with first publication rights granted to the journal.

This is an open-access article distributed under the terms and conditions of the Creative Commons Attribution license (http://creativecommons.org/licenses/by/3.0/). 